index-fossil of a zone must be distributed "all through its zone," and what he means by this expression. I am sure that he does not expect to find the chosen fossil in every foot of the chalk which makes up the zone. I suppose, therefore, be means that it ought to occur at frequent intervals throughout the zone, and that the total thickness of beds in which it does occur should be greater than that of those in which it does not.

I greatly wish that fossils would occur in such a well-regulated manner, but unfortunately their behaviour often falls sadly short of what we should like it to be. Mr. Brydone must surely have forgotten that Marsupites is not a common fossil throughout the zone of which it is accepted as the index. In fact, it is common only in the Marsupites band or subzone, and is rare or absent in the Uintacrinus band. Yet I am not aware that anyone has objected to its being used as the index-fossil of the zone, and I sincerely hope that no such objection will ever be taken.

Again, has Mr. Brydone considered the case of the zone of Act. quadratus, where that species (as now restricted) only occurs rarely, especially in the higher part of the zone. It is true that $\mathrm{Mr}$. Rowe has proposed to take Offaster pilula as the index-fossil, because it is common throughout, but this generally occurs at intervals only, being common in spots or in bands and rare or absent in the intermediate beds, just as Ostrea lunata seems to be absent from certain beds in the Trimmingham Chalk.

From the succession of beds given by Mr. Brydone on p. 14 of this Magazine, and assuming his group 3 to be identical with part of his group 4 , it is seen that 0 . lunata occurs abundantly at four horizons in the series, and that it occurs in all three divisions. This is quite sufficient to satisfy all reasonable demands on any fossil for qualification as the index of a zone; consequently I must maintain - the propriety of my choice, and must object to any other species being substituted for Ostrea lunata, unless a much better reason can be given than that advanced by Mr. Brydone.

A. J. Jukes-Browne.

Floriston, Torqtax.

\title{
DISCOVERY OF EXOGYRA SINUATA IN THE LOWER GREENSAND OF CULHAM, NEAR OXFORD.
}

SIR, - It might interest your readers to hear of the finding of a specimen of Exogyra sinuata by Mr. W. D. Hutchinson and myself in the Lower Greensand of Culham, near Oxford.

The specimen is a large one, and was found in a bed of coarse laminated sandstone, in a neighbourhood where the Greensand has been considered unfossiliferous.

Clinton G. E. Dawkins

6, Larkstone Trrrace, Ilfracombe.

(Balliol College, Oxford). 